\title{
PERSONAL NAMES IN THE POLISH, SLOVAKIAN, AND CZECH ANTHROPONYMIC SYSTEMS DERIVED FROM A LATIN NAME THAT DENOTES A PLANT
}

\author{
Gergana PETKOVA \\ Medical University of Plovdiv, Bulgaria \\ E-mail: Gergana.Petkova@mu-plovdiv.bg; gi4e82ap@abv.bg \\ Vanya IVANOVA \\ Paisii Hilendarski University of Plovdiv, Bulgaria \\ E-mail: vantod@uni-plovdiv.bg
}

\begin{abstract}
The research object of the present text is Polish, Slovakian, and Czech personal names derived from a name which is Latin by origin and denotes a plant. The main aim is to present their full list as well as their initial meaning.

Specialized anthroponymic dictionaries are used as the main source of information for excerpting the researched anthroponyms. All of them contain information not only about the different name forms, but also about their etymology, origin, and canonization.

The researched anthroponyms are divided into three major groups according to: 1) the meaning of the appellative (i. e. a thematic classification); 2) the type of the basic word (i. e. if the researched anthroponym is derived directly from an appellative or via another anthroponym (in this case a Roman gentile name or a Neolatin name)); 3) their canonization.

All personal names included in this research are a part of the modern Polish, Slovakian, and Czech anthroponymicons, even though they represent a small group with relatively infrequent usage, the initial meaning of which is not completely clear to everybody nowadays. That is why it is of great importance to reveal the basic appellative.
\end{abstract}

KEYWORDS: Polish, Slovakian, Czech, personal name, Latin, plant

Due to various historical reasons an influence of different foreign cultures may be observed on the Slavonic countries, which has left permanent traces during the ages not only in their languages, but in their anthroponymic systems as well. Consequently, it is interesting to answer the questions how foreign names enter West Slavonic name pools and how they are used by the local people.The personal names in every anthroponymic system may be divided into two big groups according to their origin local and foreign. Polish, Slovakian, and Czech local forenames are, of course, Slavonic, while the foreign ones may be grouped according to their origin as follows: Hebrew, Greek, Latin, West-European (for example, English, Italian, Spanish, German, Romanian, French, etc.), and other Slavonic forenames (for instance, Russian, Bulgarian, etc.) (Kovachev, 1987, p. 16-17). There are two major ways and periods of foreign names invasion. The first influence may be dated back to the the $9^{\text {th }}-10^{\text {th }} \mathrm{c}$. AD when Christianity became the official religion for the Slavonic people and mostly Greek, Latin, and Hebrew names were introduced. Later on, at the end of the $20^{\text {th }} \mathrm{c}$. AD West-European names became, and still are, popular and fashionable (Kovachev, 1987, p. 15-16). The research object of the present text is 12 Polish personal names ( 4 male and 8 female), 8 Slovakian ( 2 male and 6 female), and 10 Czech ones ( 3 male and 7 female), derived from an appellative, Latin by origin, that denotes a plant. The main aim is to present their full list along with their initial meaning. As a main source of information for excerpting the researched anthroponyms specialized anthroponymic dictionaries are used as well as some websites. All of them contain information not only about the different name forms, but also about their etymology, origin, and canonization. The researched anthroponyms are divided into three major groups according to: 1) the meaning of the appellative (i. e. a thematic classification); 2) the type of the basic word (i. e. if the researched anthroponym is derived directly from an appellative or via another anthroponym (in this case a Roman gentile name or a Neolatin name); 3) their canonization.

All personal names included in this research are a part of the modern West Slavonic anthroponymicons, even though they represent a small group with relatively infrequent usage, the initial meaning of which is not completely clear to everybody nowadays. That is why it is of great importance to reveal the basic appellative. Each one of the researched anthroponyms became part of the West Slavonic name systems and still is for different reasons - in the past it was used to protect the new-born or to wish him/ her good fortune, and it is retained and still encountered nowadays because of the well- 
known tradition for a baby in a given young family to be named after one of his/ her grandparents. The extralinguistic information about canonization is also important. That is one of the possible reasons why some Roman gentile names and Neo-Latin anthroponyms continue to be common and widespread, but their function now as saints' names is slightly different and their initial meaning and usage is faded or forgotten, too.

1. Thematic classification:

A. $\quad$ A tree or its fruit/ flower: laurus, $\boldsymbol{i}, \boldsymbol{f}$ /laurus, us, $\boldsymbol{f}$ - "bay tree, laurel tree" > Laurus (> PL: Laurus; SLK: Laurus)/ Laura (> PL: Laura; SLK: Laura; CZ: Laura); oliva, ae, f - "olive, olive tree" > Oliva (> PL: Oliwia; SLK: Olívia; CZ: Olivie);

B. $\quad$ A bush or its fruit/ flower: rosa, ae, $f$ - "rose" > Rosa (> PL: Róża; SLK: Róza; CZ: Róza)/ Rosalia/ Rosaria (> PL: Rozalia; SLK: Rozália; CZ: Rozálie); virga, ae, f - “vine” > Verginius/ Virginius (> PL: Wirginiusz; SLK: Virgín; CZ: Virgin);

C. $\quad$ A herbaceous plant or its fruit/ flower: cornum, i, n - "strawbery" > Cornelius (> PL: Kornel; SLK: Kornel; CZ: Kornel); faba, ae, f- "bean”> Fabius (> PL: Fabiusz; SLK: Fábius; CZ: Fabius); lilium, ii, $n$ - “lily" > Lilia (> PL: Lilia); lilium, ii, $n$ - "lily” > Liliana (> PL: Liliana; SLK: Liliana; CZ: Liliana); viola, ae, $f$ - “violet” > Viola (> PL: Wiola; SLK: Viola; CZ: Viola)/ Violetta (> PL: Wioletta; SLK: Violeta; CZ: Violeta).

The answer to the question why some anthroponyms are derived from certain names of plants and why some are preferred to others could be found in the extralinguistic information about them, i. e. their place in the mythology, in folklore traditions, or in the Chrtistian religion. That is the reason why such additional data is very important for the present text.

For example, a rose symbolizes eternity, fertility and pure love (Cooper, 1993, p. 183-184), the bean is a symbol of magic power, immortality; the plant of the Roman god Silvanus (Ibidem, p. 16)), the bay-tree is a symbol of victory; as an evergreen tree it is a sign of eternity and immortality (Ibidem, p. 113)), a violet is a symbol of modesty and beauty (Ibidem, p. 215)), a lily is a symbol of purity and peace (Ibidem, c. 115), an olive/ the olive tree is a symbol of immortality, fertility, peace (Ibidem, p. 129) and so on and so forth. When the new religion of Christianity appeared, all the old heathen beliefs and cults changed together with everything symbolic, connected with them. All the names derived from an appellative for a plant were retained in the researched West Slavonic name pools due to the two very strong traditions mentioned above - such a name is given to the child, especially a girl, as a wish to become as beautiful as the flower, or she/he is named after one of the paternal or maternal grandparents who is the proud owner of a floral onym.

2. Classification according to the type of the basic word:

A. Male Slavonic anthroponyms, derived from a Latin name that is coined from an appellative for a plant :

a. $\quad$ Anthroponyms, derived from a Roman gentile name: Cornelius ( $<$ cornum, i, $\mathrm{n}-$ "strawberry") > PL: Kornel; SLK: Kornel; CZ: Kornel; Fabius (< faba, ae, f - "bean") > PL: Fabiusz; SLK: Fábius; CZ: Fabius; Verginius/Virginius (<virga, ae, f - "vine") > PL: Wirginiusz; SLK: Virgín; CZ: Virgin;

b. $\quad$ Antroponyms, derived from a Neolatin name: Laurus (< laurus, i, f/ laurus, us, f - "bay tree, laurel tree") > PL: Laurus; SLK: Laurus;

B. $\quad$ Female Slavonic anthroponyms, derived from a Latin name that is coined from an appellative for a plant:

a. $\quad$ Antroponyms, derived from a Neo-Latin name: Laura (< laurus, i, f/ laurus, us, f - "bay tree, laurel tree") > PL: Laura; SLK: Laura; CZ: Laura; Lilia (< lilium, ii, n - "lily") > PL: Lilia; Liliana (< lilium, ii, n - "lily") > PL: Liliana; SLK: Liliana; CZ: Liliana; Oliva (< oliva, ae, f - "olive, olive tree") > PL: Oliwia; SLK: Olívia; CZ: Olivie; Rosa (< rosa, ae, f - "rose") > PL: Róża; SLK: Róza; CZ: Róza; Rosalia/ Rosaria (< rosa, ae, f - "rose") > PL: Rozalia; SLK: Rozália; CZ: Rozálie; Viola (< viola, ae, f - "violet") > PL: Wiola; SLK: Viola; CZ: Viola; Violetta (< viola, ae, f - "violet") > PL: Wioletta; SLK: Violeta; CZ: Violeta;

All the researched West Slavonic personal names are not directly derived from a Latin appellative but from a foreign name, be it a Roman gentile name or a Neo-Latin one, that denotes a 
plant. This observation may be followed by the conclusion that it is not the influence of the Latin language on the Slavonic culture that is so strong but that of the Christianity in its role as an official religion, because even the Neo-Latin names are somehow symbolic and show Christian virtues.
3. $\quad$ Classification according to canonization:
A. Names of saints, canonized by the Catholic church:
a. $\quad$ Female names of saints: Oliva, Violetta;
B. Names of saints, canonized by the Orthodox church:
b. $\quad$ Female names of saints: Lilia;
C. Names of saints, canonized by the Catholic as well as the Orthodox church:
a. $\quad$ Male names of saints: Cornelius, Fabius, Laurus;
b. $\quad$ Female names of saints: Laura, Rosa, Rosalia/ Rosaria, Viola.

Eleven Latin anthroponyms out of the 14 ones included in the research are connonized.

\section{Conclusions:}

1) There are 3 major groups of personal names, denoting a plant:

- $\quad$ anthroponyms derived from an appellative with the meaning of a tree or its fruit/flower including 8 onyms, 3 of which are Polish personal names ( 1 male and 2 female), 3 Slovakian (1 male and 2 female), and 2 Czech ones ( 2 female);

- $\quad$ anthroponyms derived from an appellative with the meaning of a bush or its fruit/flower including 9 onyms, all of which are feminine (3 Polish personal names, 3 Slovakian, and 3 Czech ones); and

- $\quad$ anthroponyms derived from an appellative with the meaning of a herbaceous plant or its fruit/flower including 16 onyms: 6 Polish personal names ( 2 male and 4 female), 5 Slovakian ( 2 male and 3 female), and 5 Czech ones ( 2 male and 3 female);

2) There are 2 major groups according to the type of the basic word:

- $\quad$ anthroponyms, derived from a Roman gentile name including 9 onyms, all of them feminine by gender, 3 of which are Polish personal names, 3 Slovakian anthroponyms, and 3 Czech ones; and

- $\quad$ anthroponyms, derived from a Neolatin name including 25 onyms: 10 Polish personal names ( 1 male and 9 female), 8 Slovakian ( 1 male and 7 female), and 8 Czech ones ( 7 female);

3) There are 3 major groups according to the canonization of the researched personal names:

- $\quad$ names of saints, canonized by the Catholic church ( 2 female anthroponyms);

- $\quad$ names of saints, canonized by the Orthodox church (1 female anthroponym);

- names of saints, canonized by the Catholic church as well as by Orthodox one -8 anthroponyms ( 3 male and 5 female).

Index of Latin anthroponyms that denote a plant and their Slavonic equivalents

Male anthroponyms:

Cornelius (< cornum, i, n - "strawberry" $\left.\left(\mathrm{K}^{1}\right)\right)>$ PL: Kornel (K, KN, LEK) (Kornelek (K, LEK), Korneli (K, LEK), Korneliusz (K, KN, LEK, PPL)); SLK: Kornel (LEK, SDS, SSJ) (Korneliusz (LEK), Kornelko (SSJ)); CZ: Kornel (K, KN, LEK) (Kornelek (K, KN), Kornelius (K, KN), KorneliusZ $($ LEK));

Fabius (< faba, ae, f - "bean" (K, KN, LEK, SDS, WO)) > PL: Fabiusz (K, LEK); SLK: Fábius (SDS) (Fabius (SSJ)); CZ: Fabius (K, KEB) (Fabouš (K), Faboušek (K));

Laurus (< laurus, i, f/ laurus, us, f - "bay tree, laurel tree" (K, KN, KSI, SDS, WO)) > PL: Laurus (LEK) (Laurek (K), Wawrzek (K), Wawrzuś (K)); SLK: Laurus (SDS, SSJ) (Lauro (SSJ), Vavrín (SSJ), Vavro (SSJ), Vavruško (SSJ), Vavrušo (SSJ));

Verginius/Virginius (< virga, ae, f - "vine" $(\mathrm{K}, \mathrm{KN}))>$ PL: Wirginiusz $(\mathrm{K}, \mathrm{KN}, \mathrm{LEK})$; SLK: Virgín (LEK, SDS); CZ: Virgin (K, KN, LEK, SDS) (Virginek (K, KN));

\footnotetext{
${ }^{1}$ For the sources of excerption the following abbreviations are used: $\mathbf{K}=$ http://kurufin.ru/; $\mathbf{K N}=$ Knappová 1985; KSI = www.ksiegaimion.com; SSJ = Slovník slovenského jazyka, VI; WO = Wood 2002.
} 


\section{Female anthroponyms:}

Laura (<laurus, i, f/ us, f - "bay tree, laurel tree" $(\mathrm{K}))>$ PL: Laura (K, KN, KSI, LEK) (Laurka (K, KSI, LEK)); SLK: Laura (SDS, SSJ); CZ: Laura (K, KN) (Laurenka (K, KN), Laurka (K, KN), Lauřička $(\mathrm{K}, \mathrm{KN})$, Loreta $(\mathrm{KN})$, Loretka $(\mathrm{KN}))$;

Lilia (< lilium, ii, n - "lily" (K, KN, LEK, WO)) > PL: Lilia (K, LEK) (Lillia (LEK));

Liliana (< lilium, ii, n - "lily" (K, KN, SDS, WO)) > PL: Liliana (K, KN, LEK) (Lilianka (K, LEK), Lilianna (LEK)); SLK: Liliana (SDS, SSJ) (Lilianka (SSJ)); CZ: Liliana (K, KN);

Oliva (< oliva, ae, f - "olive, olive tree" (K, KN, SDS, WO)) > PL: Oliwia (K, LEK) (Oliwka (K), Oliwcia (K)); SLK: Olívia (SDS, SSJ) (Oliva (LEK, SDS, SSJ), Olivia (LEK)); CZ: Olivie (K, $\mathrm{KN}$, LEK) (Oliva (K, KN), Olivka (K, KN), Olivuška (K, KN));

Rosa (< rosa, ae, f - "rose" (K, KN, LEK, SDS, WO)) > PL: Róża (K, KN, LEK, PPL, SDS) (Roza (K, LEK), Rożyczka (LEK), Rózia (K, LEK), Różyczka (K)); SLK: Róza (SDS, SSJ) (Rozália (LEK, SDS, SSJ), Rozálka (SSJ), Rozála (SDS, SSJ), Rozára (SDS, SSJ), Rozárka (SSJ), Rozeta (SDS, SSJ), Rozetka (SSJ), Rozita (SDS), Rózika (SSJ), Rózička (SSJ), Rózka (SSJ)); CZ: Róza (KN) (Rosa $(\mathrm{KN})$, Rosana $(\mathrm{KN})$, Rozálie (KN), Rozana (KN), Rozanka (KN), Rozára (KN), Rozárka (KN), Rózka $(\mathrm{KN})$, Rozina (KN), Rózička (KN), Rozita (KN), Rozitka (KN));

Rosalia/ Rosaria (< rosa, ae, f - "rose" (K, KN, WO)) > PL: Rozalia (K, KN, LEK, PPL) (Rozalinda (LEK), Rozalka (K, LEK)); SLK: Rozália (LEK, SDS, SSJ) (Rozalina (LEK), Rozalína (SSJ), Rozalínka (SSJ), Rozála (SDS, SSJ)); CZ: Rozálie (K, KN, LEK) (Rozálka (K, KN));

Viola (< viola, ae, f - "violet" (K, KN, LEK, SDS, WO)) > PL: Wiola (K, LEK) (Wiolcia (K, LEK), Wiolka (K, LEK)); SLK: Viola (LEK, SDS, SSJ) (Violenka (SSJ), Violka (SSJ), Violuška (SSJ)); CZ: Viola (K, KN, LEK) (Violka (K, KN));

Violetta (< viola, ae, f - "violet" (K, KN, LEK, SDS, WO)) > PL: Wioletta (K, KN, LEK) (Violeta (LEK), Wiola (K), Wiolcia (K), Wioleta (K, LEK), Wioletka (K, LEK), Wiolka (K)); SLK: Violeta (LEK, SDS); CZ: Violeta (K, KN, LEK) (Violetka (KN)).

\section{List of abbreviations: \\ PL - Polish; \\ SLK - Slovakian; \\ $\mathbf{C Z}$ - Czech}

\section{REFERENCES:}

Ковачев, Н. (1987) Българска ономастина (наука за собствените имена). София: Индекс 80. (Kovachev, N. Balgarska onomastika (nauka za sobstvenite imena). Sofiya: Indeks 80.)

Купър, Дж. К. (1993) Илюстрована енциклопедия на традиционните символи. София: Издателство Петър Берон. (Cooper, J., K. Ilyustrovana entsiklopediya na traditsionnite simvoli. Sofia: Izdatelstvo Petar Beron.)

Knappová, M. (1985) Jak se bude jmenovat? Praha: Academia.

Slovník (1968) Slovník slovenského jazyka, VI. Bratislava: Vydavatel'stvo SAV.

Wood, E. (2002) The Virgin Book of Baby Names. London: Virgin Books.

KSI Wielka Księga Imion <www.ksiegaimion.com> (5.03.2021).

$\mathbf{K}$

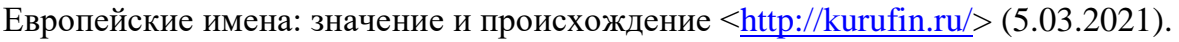

